\title{
HB-EGF regulates Prss56 expression during mouse decidualization via EGFR/ERK/EGR2 signaling pathway
}

\author{
Jie Liu1,2, Fei Gao², Yue-Fang Liu', Hai-Ting Dou', Jia-Qi Yan', Zong-Min Fan'1 and \\ Zeng-Ming Yang ${ }^{1}$
}

'College of Veterinary Medicine, South China Agricultural University, Guangzhou, China

2Department of Biology, Shantou University, Shantou, China
Correspondence should be addressed to Z-M Yang Email

zmyang@scau.edu.cn

\begin{abstract}
Embryo implantation and decidualization are key steps for successful reproduction. Although numerous factors have been identified to be involved in embryo implantation and decidualization, the mechanisms underlying these processes are still unclear. Based on our preliminary data, Prss56, a trypsin-like serine protease, is strongly expressed at implantation site in mouse uterus. However, the expression, regulation and function of Prss56 during early pregnancy are still unknown. In mouse uterus, Prss56 is strongly expressed in the subluminal stromal cells at implantation site on day 5 of pregnancy compared to inter-implantation site. Under delayed implantation, Prss56 expression is undetected. After delayed implantation is activated by estrogen, Prss56 is obviously induced at implantation site. Under artificial decidualization, Prss56 signal is seen at the primary decidual zone at the initial stage of artificial decidualization. When stromal cells are induced for in vitro decidualization, Prss56 expression is significantly elevated. Dtprp expression under in vitro decidualization is suppressed by Prss56 siRNA. In cultured stromal cells, HB-EGF markedly stimulates Prss56 expression through EGFR/ERK pathway. Based on promoter analysis, we also showed that Egr2 is involved in Prss56 regulation by HB-EGF. Collectively, Prss56 expression at implantation site is modulated by HB-EGF/ EGFR/ERK signaling pathway and involved in mouse decidualization.
\end{abstract} Key Words

Journal of Endocrinology (2017) 234, 247-254

\section{Introduction}

Embryo implantation is the attachment of the embryo to the uterine luminal epithelium followed by invasion of embryos into the underlying stromal bed. Once embryos are implanted, uterine stromal cells will undergo decidualization (Hantak et al. 2014). Both embryo implantation and decidualization are synchronized and coordinated under the regulation of ovarian estrogen and progesterone (Wang \& Dey 2006). However, the molecular mechanism underlying embryo implantation and decidualization is still unclear.
Proteolytic enzymes consist of over $2 \%$ of the known proteome and participate in many essential biological processes. The serine proteases constitute one of the largest families of proteolytic enzymes that are well recognized for their pivotal roles in physiological processes as diverse as development, digestion, coagulation, inflammation and immunity (Antalis et al. 2011). Serine proteinase is involved in the matrix degradation required for implantation (Salamonsen 1999). Trypsin-like serine protease is a kind of serine proteases possessing similar

Published by Bioscientifica Ltd 
activity as trypsin and specifically cleaved peptides with positively charged lysine or arginine (Evnin et al. 1990). Through activation of protease-activated receptors (PARs), trypsin-like serine proteases exert their roles among physiologic and pathologic processes (Hollenberg et al. 2014).

Among serine proteinases, implantation serine proteinase 1 (ISP1) encodes the embryo-derived enzyme strypsin, which is necessary for blastocyst hatching in vitro and the initiation of invasion. The ISP2 gene is expressed in endometrial glands and is regulated by progesterone during the peri-implantation period (O'Sullivan et al. 2004). Inhibition of ISP2 can significantly reduce the number of implantation sites in mice (Huang et al. 2004). Prss23 is strongly expressed in uterine luminal epithelium during mouse preimplantation period, and Prss35 is mainly expressed in subluminal stromal cells on days 5 and 6 of pregnancy (Diao et al. 2013).

Based on our preliminary microarray analysis on mouse uterus, Prss56 mRNA level at implantation site is significantly higher than that at inter-implantation site. Prss56 (protease, serine, 56, also called MCOP6 or Rik1700027L120) is a putative serine protease. Prss56 protein is predicted to be a secreted trypsin-like serine protease peptidase (Gal et al. 2011). However, the expression, regulation and function of Prss56 during early pregnancy are still unknown. In this study, we showed that Prss56 expression during decidualization is regulated by HB-EGF/EGFR/ERK/Egr2 signaling pathway.

\section{Materials and methods}

\section{Animals and treatment}

Mature CD1 mice used in this study were obtained from Hunan Slack Laboratory Animal Co., LTD. Mice were maintained under a specific pathogen-free (SPF) and controlled environment with a 12-h light:12-h darkness cycle. Animal experiment procedures were approved by the Animal Care and Use Committee of South China Agricultural University. Female mice were co-caged with fertile or vasectomized males in cages to induce pregnancy or pseudopregnancy. Day 1 of pregnancy or pseudopregnancy is the day of vaginal plug. Uteri at different time points were collected and flash-frozen for further analysis. Successful pregnancy was confirmed by flushing embryos from the uteri or oviducts from days 1 to 4 . Tail intravenous injection with $0.1 \mathrm{~mL}$ of $1 \%$ Chicago blue dye (Sigma-Aldrich) was applied to identify implantation sites on days 5 and 6 . The decidua can be visualized directly on days 7 and 8 .

Models of artificial decidualization and delayed implantation were performed as previously described (Liang et al. 2014). Briefly, $10 \mu \mathrm{L}$ sesame oil (Sigma) was instilled into one uterine horn of female adults to induce deciduoma and the un-injected contralateral horn as control. Mice were killed on the day 5 or day 8 post vaginal plug. For delayed implantation, pregnant mice were ovariectomized on day 4 of pregnancy and subcutaneously injected with progesterone $\left(\mathrm{P}_{4}\right.$, $1 \mathrm{mg} / 0.1 \mathrm{~mL}$ sesame oil/mouse; Sigma) from day 5 to 7. Delayed implantation was terminated by an injection of $25 \mathrm{ng} /$ mouse estradiol-17 $\beta\left(\mathrm{E}_{2}\right.$, Sigma) on day 7 . Mice were then killed on day 8. Implantation sites were identified by tail intravenous injection with Chicago blue $24 \mathrm{~h}$ after estrogen injection.

\section{Transfer of HB-EGF-soaked beads}

Affi-Gel blue Gel Beads (Bio-Rad, \#1537301) of similar size with blastocyst were incubated with HB-EGF (heparinbinding EGF-like growth factor, $100 \mathrm{ng} / \mu \mathrm{L}$ ) in $0.1 \% \mathrm{BSA} /$ PBS under $37^{\circ} \mathrm{C}$. After 1 -h incubation, beads were washed with PBS at least three times. The HB-EGF-loaded beads (7-9 beads/horn) were transplanted into uterine lumen of day 4 pseudopregnant mice. Beads incubated with $0.1 \% \mathrm{BSA} / \mathrm{PBS}$ were transplantated into the other horn as control. Mice were killed for further analysis $24 \mathrm{~h}$ after the transplantation.

\section{In situ hybridization}

The cDNA fragment of each target gene was amplified with specific PCR primers (Table 1) and cloned into pGEM-T easy vector (Promega). After the direction of each insert ligated to the vector was verified, antisense or sense cRNA probes were synthesized in vitro by a digoxigenin RNA labeling kit (Roche Applied Science).

In situ hybridization was performed as previously described (Lei et al. 2012). Briefly, frozen sections were fixed in $4 \%$ PFA, hybridized for $16 \mathrm{~h}$ at $55^{\circ} \mathrm{C}$, washed and incubated with sheep anti-digoxigenin antibody conjugated to alkaline phosphatase (1:5000, Roche) overnight. The signal was visualized with nitroblue tetrazolium (NBT, $0.4 \mathrm{mM}$ ) and 5-bromo-4-chloro-3indolyl phosphate (BCIP, $0.4 \mathrm{mM}$ ) used as reaction substrates. Endogenous alkaline phosphatase activity was inhibited with $2 \mathrm{mM}$ levamisole. Sections were counterstained with $1 \%$ methyl green.

Published by Bioscientifica Ltd. 
Table 1 Primers used in this study.

\begin{tabular}{|c|c|c|c|c|}
\hline Gene & Primer sequences & Accession no. & Size (bp) & Application \\
\hline \multirow[t]{2}{*}{ Egr1 } & GAGCGAACAACCCTATGAG & NM_007913 & 102 & Real-time PCR \\
\hline & GTCGTTTGGCTGGGATAA & & & \\
\hline siEgr1-1 & CCAACAGTGGCAACACTTT & & & siRNA transfection \\
\hline siEgr1-2 & CCTTCGCTCACTCCACTAT & & & siRNA transfection \\
\hline \multirow[t]{2}{*}{ Egr2 } & САССТССТТССТАСССАТ & NM_010118.3 & 433 & In situ hybridyzation \\
\hline & ААССТССТАТСАСААССТTC & & & \\
\hline \multirow[t]{2}{*}{ Egr2 } & CTCCCGTATCCGAGTAGC & NM_010118.3 & 144 & Real-time PCR \\
\hline & GATGCCCGCACTCACAAT & & & \\
\hline siEgr2-1 & GCTGCTATCCATAAGGTAT & & & siRNA transfection \\
\hline siEgr2-2 & GCATGATCAACATTGACAT & & & siRNA transfection \\
\hline \multirow[t]{2}{*}{ Prss56 } & ATTGCGGCGTGGAGTC & NM_027084 & 551 & In situ hybridyzation \\
\hline & AGGGTTGCCTGGTTCA & & & \\
\hline \multirow[t]{2}{*}{ Prss56 } & GGCTGCACATTGCTTCG & NM_027084 & 132 & Real-time PCR \\
\hline & TGCGGGTCAAACTTAGGG & & & \\
\hline siPrss56-1 & GCCTCTGCAACAGAAGTTA & & & siRNA transfection \\
\hline siPrss56-2 & GCTTGGAACCTTCCACACT & & & siRNA transfection \\
\hline \multirow[t]{2}{*}{ Dtprp } & AGCCAGAAATCACTGCCACT & NM_010088 & 119 & Real-time PCR \\
\hline & TGATCCATGCACCCATAAAA & & & \\
\hline \multirow[t]{2}{*}{$R p / 7$} & GCAGATGTACCGCACTGAGATTC & M29016 & 129 & Real-time PCR \\
\hline & ACCTTTGGGCTTACTCCATTGATA & & & \\
\hline Negative control & CTCCGAACGTGTCACGT & & & siRNA transfection \\
\hline
\end{tabular}

\section{Isolation and treatments of endometrium stromal cells}

Endometrial stromal cells were isolated as previously described (Lei et al. 2012). Stromal cells were cultured with DMEM/F12 (Sigma) containing 10\% (w/v) charcoalstripped FBS (cFBS, Biological Industries, Beit Haemek, Israel). Cells were treated with HB-EGF $(50 \mathrm{ng} / \mathrm{mL}, \mathrm{R} \& \mathrm{D}$ Systems) fordifferent time points. Correspondingly, cells treated with $1 \%$ BSA/PBS were regarded as the control. For the inhibition experiments, EGFR (EGF receptor) inhibitor ( $2 \mu \mathrm{M}$, Calbiochem, \#364274) or ERK (extracellular regulated protein kinase) inhibitor U0126 (10 $\mu \mathrm{M}$, Cell signaling Technology, \#9903S) were used in this study.

To induce stromal cells to undergo decidualization, $\mathrm{E}_{2}$ combined with $\mathrm{P}_{4}$ was used to treat cells for different time points, in the concentration of $10 \mathrm{nM}$ or $1 \mathrm{mM}$, respectively. Since either $\mathrm{E}_{2}$ or $\mathrm{P}_{4}$ was dissolved in ethanol, cells treated with doubled volume of ethanol were severved as the control.

\section{Transfections}

Stromal cells were transfected with siRNA against Egr1 (Early growth factor 1), Egr2 or Prss56 expression (Guangzhou Ribo Co., Ltd, Guangzhou, China) using Lipofectamine2000 kit (Invitrogen). Methods for the transfection were performed according to the manufacturer's protocol. After cells were transfected with Prss56 siRNA for $48 \mathrm{~h}$, stromal cells were induced for in vitro decidualization in DMEM/F12 containing 2\%
cFBS, $\mathrm{E}_{2}(10 \mathrm{nM})$ and $\mathrm{P}_{4}(1 \mu \mathrm{M})$ for $48 \mathrm{~h}$. Hi GC siRNA was used as a negative control. The sequences used for RNA interference are provided in Table 1.

\section{Western blot}

Cultured cells were lysed in RIPA buffer (20 mM Tris$\mathrm{HCl}, \mathrm{pH} 7.5,150 \mathrm{mM} \mathrm{NaCl}, 5 \mathrm{mM}$ EDTA, $10 \mathrm{mM} \mathrm{NaF}$, $1 \mathrm{mM} \mathrm{Na} \mathrm{VO}_{3}, 0.1 \%$ SDS, $1 \%$ Triton X-100, 1\% Sodium deoxycholate) containing protease inhibitor cocktail (Roche). Denatured protein samples were subjected to SDS-PAGE, transferred onto polyvinylidene fluoride membranes (PVDF, Millipore) and probed with antibodies against p-ERK (1:1000, Cell Signaling Technology, \#4370), ERK (1:1000, Cell Signaling Technology, \#4695) and $\alpha$-Tubulin (1:1000, Cell Signaling Technology) diluted in 5\% BSA (Sigma). Membranes were incubated in goat antirabbit antibody conjugated with horseradish peroxidase. The signals were developed in ECL Chemiluminescent kit (Thermo Fisher).

\section{RNA extraction and real-time PCR}

Total RNAs were extracted with TRIzol reagent (TaKaRa) and digested with RQ1 deoxyribonuclease I (Promega). Total RNAs (500 ng) were then reverse transcribed into cDNA with the $5 \times$ PrimeScript reverse transcriptase reagent kit (TaKaRa). Real-time PCR was performed with SYBR Premix Ex Taq kit (TaKaRa) on CFX96 TOUCHTM

Published by Bioscientifica Ltd 
(BIO-RAD). PCR conditions were as follows: $95^{\circ} \mathrm{C}$ for $3 \mathrm{~min}$, followed by 39 cycles of $95^{\circ} \mathrm{C}$ for $10 \mathrm{~s}$ and $65^{\circ} \mathrm{C}$ for $5 \mathrm{~s}$. All reactions were run in triplicate. $\Delta \Delta \mathrm{Ct}$ analysis method was used to determine the relative changes of gene expression. Rpl7, a housekeeping gene, was used to normalize data. The primer sequences used for real-time PCR are listed in Table 1.

\section{Statistical analysis}

All the experiments were independently repeated at least 3 times. Data were processed using GraphPad Prism 6 Software. $P$ values were calculated by Student's unpaired test. Statistical significance is indicated by ${ }^{*} P<0.05$.

\section{Results}

\section{Prss56 mRNA expression during early pregnancy}

In situ hybridization was used to examine the mRNA expression of Prss56 during early pregnancy. Prss56 was undetected in mouse uteri from days 1 to 3 . Signal was seen in the stromal cells under luminal epithelium on day 4.5. On day 5, Prss56 signal was strongly observed in the subluminal stromal cells at implantation site, while it was absent at inter-implantation site. On day 6, a weak signal of Prss56 was seen in the subluminal stromal cells. On days 7 and 8 , there was no detectable signal (Fig. 1). There was no detectable signal when sense probe was used for in situ hybridization (data not shown).

In order to analyze whether Prss56 expression is dependent on the presence of blastocyst, Prss56 expression was examined under delayed implantation. Under delayed implantation, Prss56 was not detected. After delayed implantation was terminated by estrogen, Prss56 expression was strongly observed in the subluminal stromal cells at implantation site, similar to that on day 5 of pregnancy (Fig. 1).

\section{Role of Prss56 during decidualization}

In mouse uterus, uterine stromal cells will undergo decidualization following embryo attachment (Wang \& Dey 2006). Additionally, decidualization can also be experimentally induced by mechanical or sesame oil stimuli (Herington et al. 2009). After sesame oil was intraluminally infused into one side of uterine horn on day 4 of pseudopregnancy, Prss56 signal was strongly detected
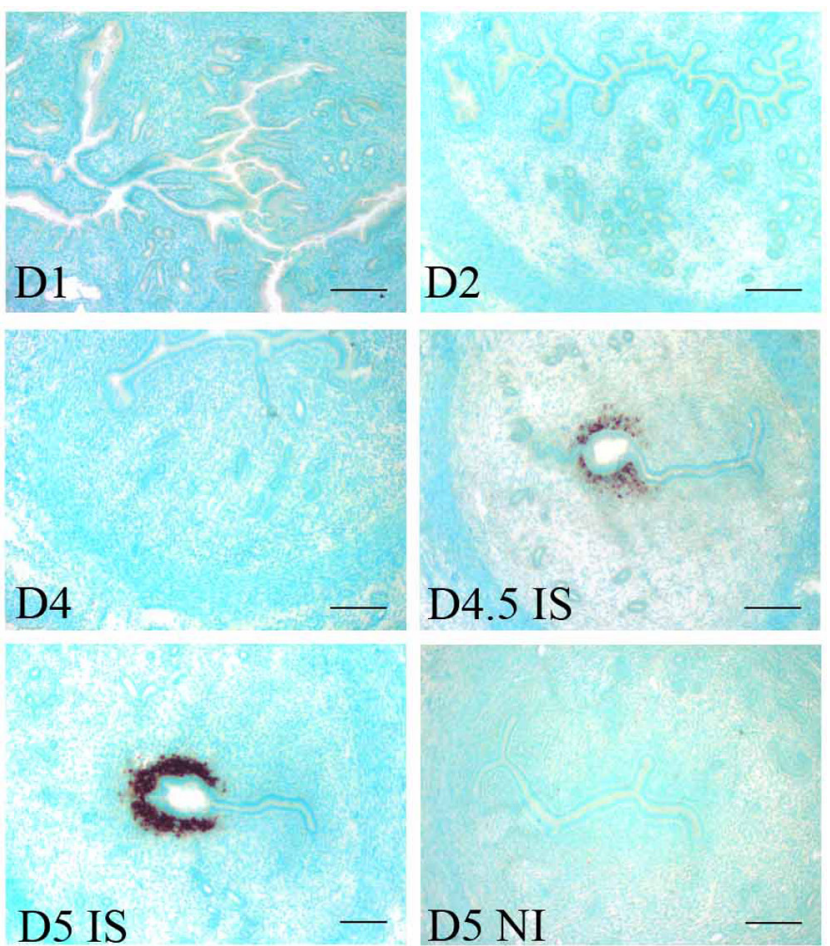

D6 IS
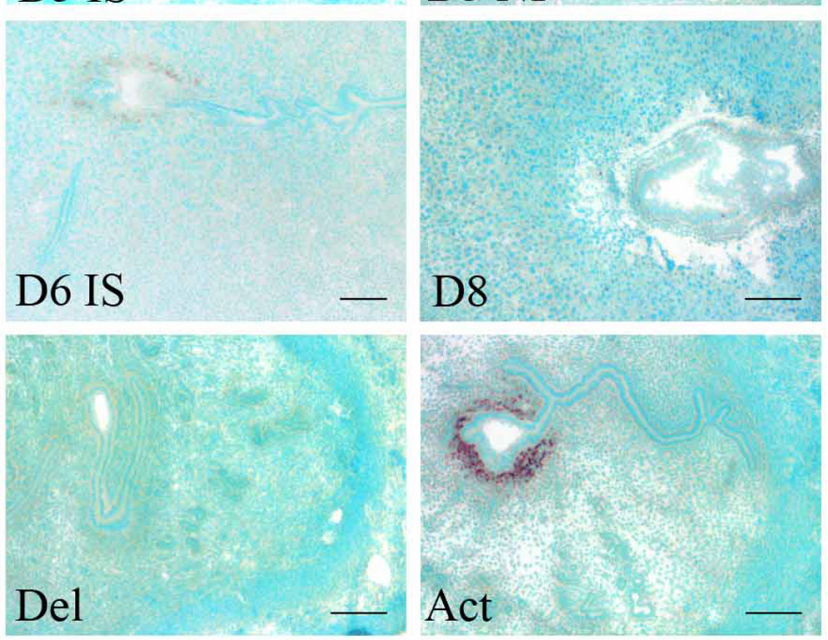

Figure 1

In situ hybridization of Prss56 in mouse uteri. During early pregnancy, Prss56 signal was strongly detected in the subluminal stromal cells on days 4.5 and 5 of pregnancy. Compared to delayed implantation, Prss56 expression was significantly induced after delayed implantation was activated by estrogen. Act, activation of delayed implantation; Del, delayed implantation; IS, implantation site; NI, non-implantation site. Scale bar $=300 \mu \mathrm{m}$.

in the subluminal stromal cells on day 5 , but not seen on day 8 of pseudopregnancy. Furthermore, Prss56 signal was not seen in the un-injected uterine horn (Fig. 2A). Because Prss56 was strongly expressed in the primary decidua, we then examined Prss56 expression under in vitro decidualization. After mouse stromal cells were induced for in vitro decidualization, decidual/trophoblast

Published by Bioscientifica Ltd 
A

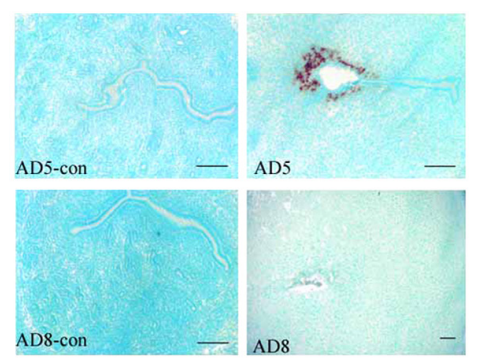

$\mathrm{B}$

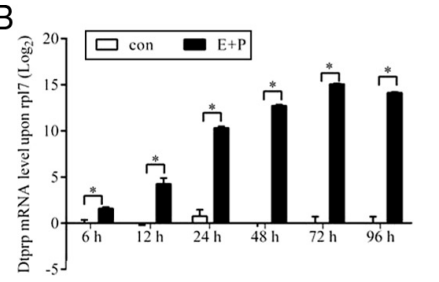

$\mathrm{C}$

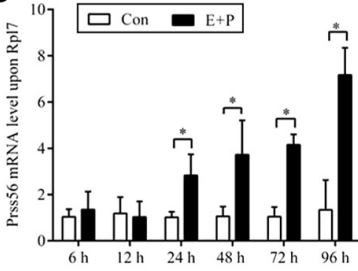

D

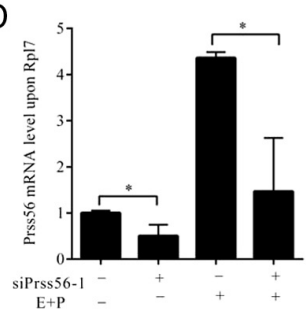

Figure 2

Prss56 mRNA expression and function during decidualization. (A) In situ hybridization of Prss56 mRNA expression under artificial decidualization. Prss 56 was expressed on the subluminal stromal cells on the day 5 of artificial decidualization but not on day 8 and control horn. AD, artificial decidualization; AD-con, the un-injected contralateral horn. (B) Real-time PCR of Dtprp expression under in vitro decidualization from $6 \mathrm{~h}$ to $96 \mathrm{~h}$. The significantly high expression of Dtprp indicates that the stromal cells were induced into decidualized cells. Con, control group; $E+P$, cells co-treated with $\mathrm{E}_{2}$ and $\mathrm{P}_{4}$. (C) Real-time PCR of Prss56 mRNA expression under in vitro decidualization. Prss56 expression was significantly upregulated compared to the control from $24 \mathrm{~h}$ to $96 \mathrm{~h}$. Con, control group; $E+P$, cells co-treated with $E_{2}$ and $P_{4}$. (D) Real-time PCR of Prss56 expression after stromal cells under in vitro decidualization were treated with Prss 56 siRNA. Prss 56 expression was significantly downregulated by Prss56 siRNA. siPrss56-1, Prss56 siRNA-1. (E) Real-time PCR of Dtprp expression after stromal cells under in vitro decidualization were treated with Prss56 siRNA. Dtprp expression was significantly inhibited by Prss56 siRNA. $E+P$, Co-treatment with $E_{2}+P_{4}$. Data are presented as mean \pm S.E.M. $(n=3)$.

prolactin-related protein (Dtprp), a marker for in vitro decidualization (Liang et al. 2010), was strongly expressed (Fig. 2B). Meanwhile, Prss56 was induced under in vitro decidualization even from $24 \mathrm{~h}$ (Fig. 2C). To further analyze the role of Prss56 during decidualization, Prss56 expression was knocked down by siRNA. After Prss56 level was suppressed by Prss56 siRNA (Fig. 2D and Supplementary Fig. 1, see section on supplementary data given at the end of this article), Dtprp expression was downregulated under in vitro decidualization (Fig. 2E).

\section{HB-EGF regulatation on Prss56 expression}

In mice, HB-EGF signal is detected at the site of the blastocyst apposition $6-7 \mathrm{~h}$ before the attachment reaction (Das et al. 1994). HB-EGF-presoaked gelatin beads can induce implantation-like responses in uterine lumen of pseudopregnant mice (Paria et al. 2001). Therefore,

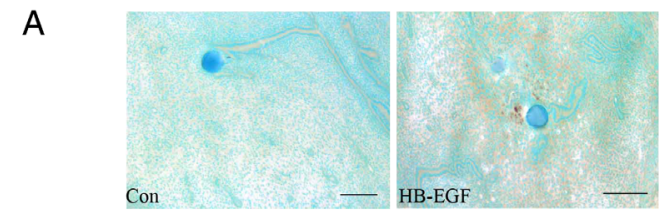

B

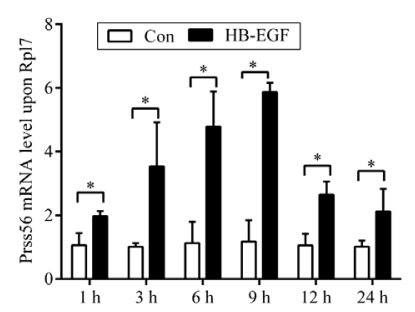

C
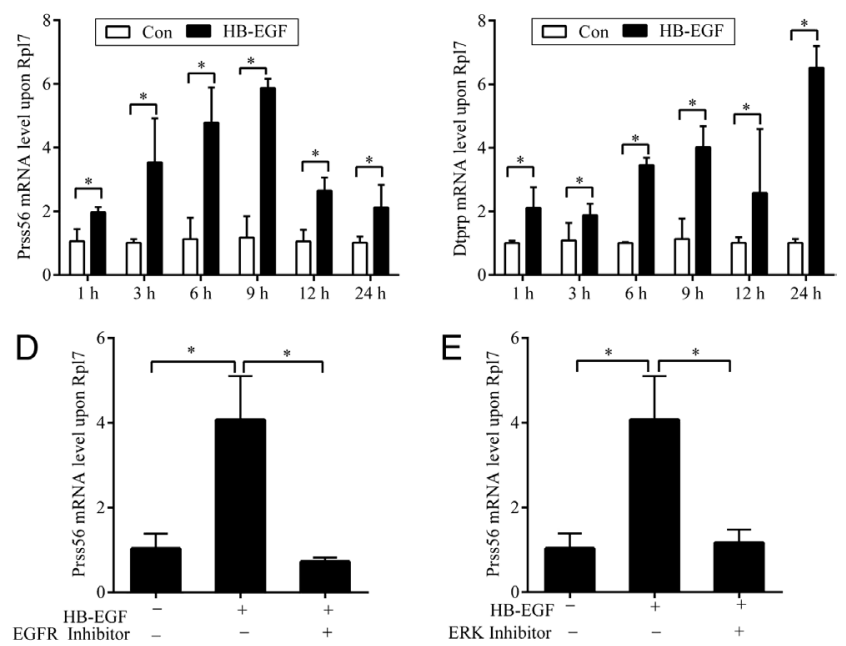

ERK Inhibitor -

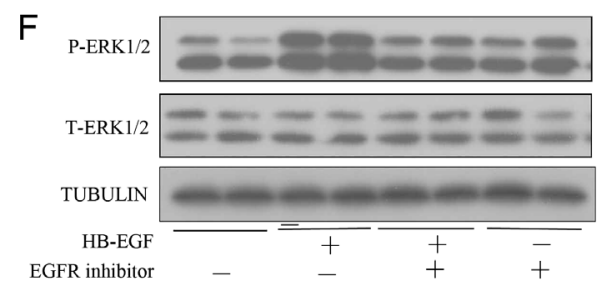

Figure 3

HB-EGF induction on Prss56 expression through EGFR-ERK pathway. (A) In situ hybridization of Prss56 expression after HB-EGF-soaked beads were transferred into uterine lumen of pseudopregnant mice. Scale bar $=300 \mu \mathrm{m}$. (B) Real-time PCR of Prss56 expression after stromal cells were treated with $\mathrm{HB}-\mathrm{EGF}(50 \mathrm{ng} / \mu \mathrm{L})$ at different time points. Cells were serum starved overnight with the medium containing $2 \%$ FBS before HB-EGF treatment. (C) Dtprp mRNA level after stromal cells were treated with HB-EGF ( $50 \mathrm{ng} / \mu \mathrm{L})$ at different time points. (D) Effects of EGFR inhibitor $(2 \mu \mathrm{M})$ on HB-EGF-induced Prss56 expression. After serum starvation overnight, cells were pre-treated with the medium containing EGFR inhibitor for $1 \mathrm{~h}$ and then treated with HB-EGF and EGFR inhibitor for $6 \mathrm{~h}$. (E) Effects of ERK inhibitor $(10 \mu \mathrm{M})$ on HB-EGF-induced Prss56 expression for $6 \mathrm{~h}$. Cells were also pre-treated with ERK inhibitor for $1 \mathrm{~h}$ before HB-EGF treatment. (F) Western blot analysis of ERK and P-ERK proteins when stromal cells were treated with HB-EGF and EGFR inhibitor. Tubulin was used as a loading control. Data were presented as mean \pm S.E.M. $(n=3)$. http://joe.endocrinology-journals.org DOI: $10.1530 / \mathrm{JOE}-16-0636$
๑ 2017 Society for Endocrinology Printed in Great Britain 
we asked whether Prss56 expression was regulated by HB-EGF. Signal of Prss56 expression can be seen in uteri of pseudopregnancy mice transplanted with beads incubated with HB-EGF but not in the control (Fig. 3A). On the other hand, after stromal cells were treated with HB-EGF, Prss56 expression was significantly induced from $1 \mathrm{~h}$ to $24 \mathrm{~h}$ after treatment (Fig. 3B). Meanwhile, Dtprp expression was obviously increased from $1 \mathrm{~h}$ to $24 \mathrm{~h}$ after HB-EGF treatment, which was similar to Prss56 expression (Fig. 3C). Because HB-EGF is a ligand of EGFR (Lim \& Dey 2009), stromal cells were treated with EGFR inhibitor to see whether HB-EGF stimulation on Prss56 is mediated by EGFR. The stimulation of HB-EGF on Prss56 was obviously abrogated by EGFR inhibitor (Fig. 3D). We have previously shown that HB-EGF regulates decidualization through ERK1/2 (Jiang et al. 2013). HB-EGF stimulation on Prss56 was also suppressed by ERK1/2 inhibitor (Fig. 3E). HB-EGF induction of p-ERK1/2 level was also abrogated by EGFR inhibitor (Fig. 3F). These data suggest that HB-EGF stimulates Prss56 expression via EGFR-ERK pathway.

\section{Egr2 regulation on Prss56 expression}

Based on our promoter analysis with JASPAR, there are Egr-binding sites in the Prss56 promoter (-2000 to $0 \mathrm{bp}$ ). We previously showed that Egr1 is strongly expressed in the subluminal stromal cells at implantation site (Liang et al. 2014). At implantation site, Prss56 expression
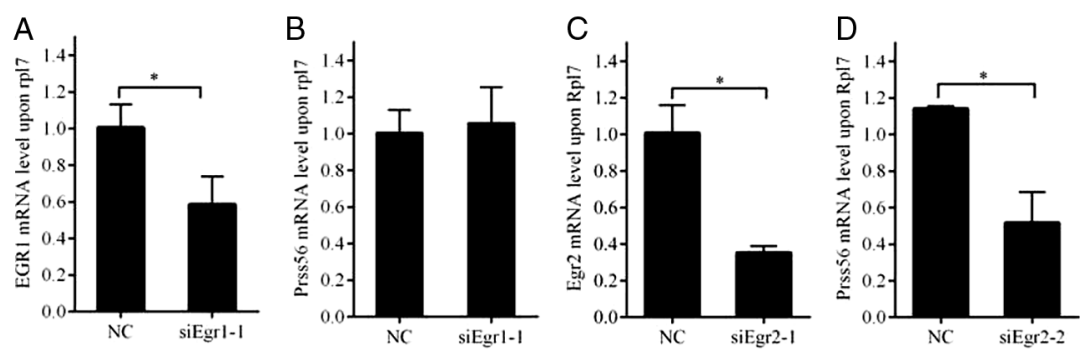
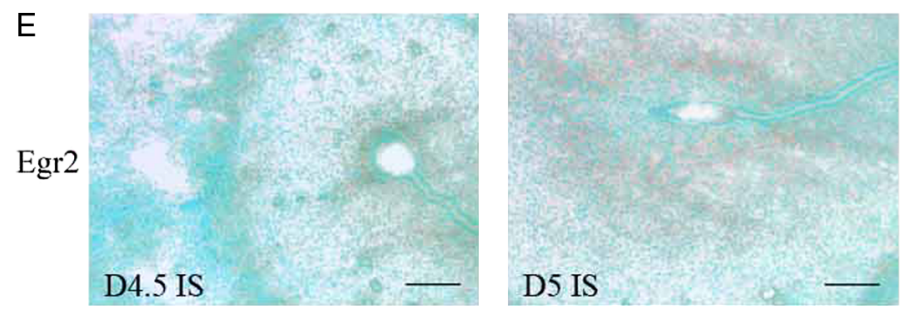

$\mathrm{F}$

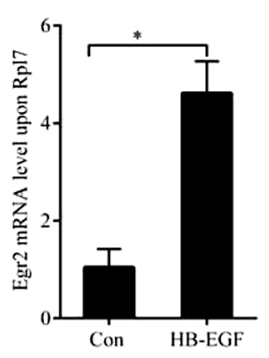

G
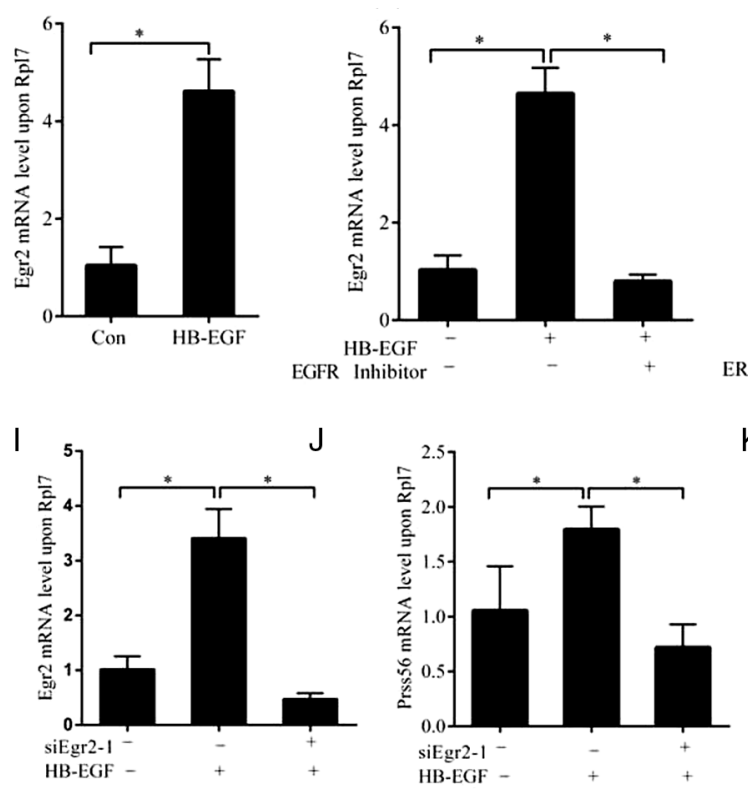

$\mathrm{H}$
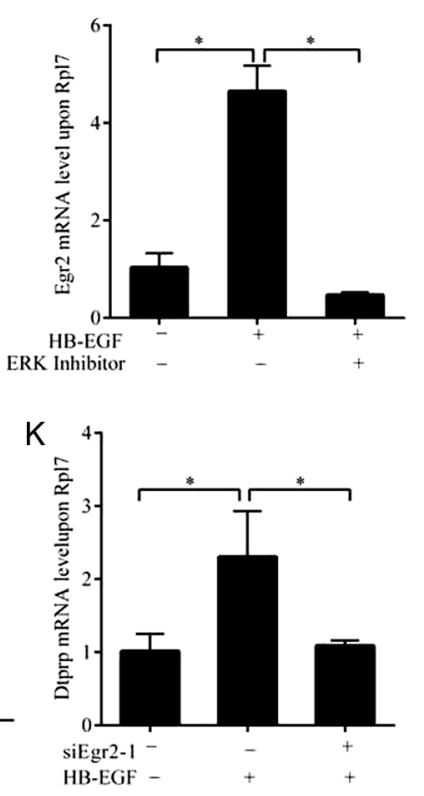

\section{Figure 4}

'Egr2 involvement in HB-EGF regulation on Prss56 expression. (A) Egr1 mRNA level after stromal cells were treated with Egr1 siRNA-1. siEgr1-1, Egr1 siRNA-1. (B) Prss56 mRNA expression after stromal cells was treated with Egr1 siRNA-1. NC, negative control. (C) Egr2 mRNA level after stromal cells were treated with Egr2 siRNA-1. siEgr2-1, Egr2 siRNA-1. (D) Prss56 mRNA level after stromal cells were treated with Egr2 siRNA-1. (E) In situ hybridization of Egr2 expression at implantation sites in mouse uteri on days 4.5 and 5 of pregnancy. IS, implantation site. Scale bar $=300 \mu \mathrm{m}$. (F) HB-EGF induction on Egr2 expression. Egr2 expresssion in the stromal cells was markedly induced by the HB-EGF. Con, control. (G) Effects of EGFR inhibitor on HB-EGF-induced Egr2 expression. In the presence of EGFR inhibitor, Egr2 was downregulated. (H) Effect of ERK inhibitor on HB-EGF-induced Egr2 expression. Induction of Egr2 by HB-EGF was inhibited by ERK inhibitor. (I) HB-EGF stimulation on Egr2 was reduced by Egr2 siRNA-1. (J) HB-EGF induction on Prss 56 was abrogated by Egr2 siRNA-1. (K) HB-EGF induction on Dtprp mRNA expression was inhibited by Egr2 siRNAData were presented as mean \pm S.E.M. $(n=3)$. 
was co-localized with Egr1. To test the effect of Egr1 and Egr2 on Prss56 expression, we knocked down Egr1 using siRNA. Although Egr1 level was reduced by Egr1 siRNA (Fig. 4A and Supplementary Fig. 1B), Prss56 expression was not affected by Egr1 knockdown (Fig. 4B). Because Egr2 is also highly expressed at implantation site on day 5 of pregnancy (Fig. 4E), and Egr1 and Egr2 share similar binding sites, we wondered whether Prss56 expression was regulated by Egr2. When Egr2 expression was knocked down by siRNA (Fig. 4C and Supplementary Fig. 1C), Prss56 expression was significantly downregulated (Fig. 4D and Supplementary Fig. 1C). When stromal cells were treated with HB-EGF, Egr2 expression was obviously increased (Fig. 4F). HB-EGF stimulation on Egr2 was also suppressed by EGFR inhibitor or ERK1/2 inhibitor (Fig. 4G and $\mathrm{H})$. Under HB-EGF treatment, HB-EGF induction on both Prss56 and Dtprp exopression was abrogated by Egr2 siRNA infection (Fig. 4I, J and K).

\section{Discussion}

In this study, Prss56 is strongly expressed in the subluminal stromal cells at implantation site. In vitro decidualization is suppressed by Prss56 siRNA. HB-EGF stimulates Prss56 expression via EGFR/ERK/Egr2 signaling pathway.

Prss56 encodes a protein containing 603 amino acids, showing similarity to trypsin-like serine proteases (Gal et al. 2011). Trypsin, an embryo-released serine protease, is required for embryo implantation through activation of epithelial $\mathrm{Na}^{+}$channel and stimulation of COX-2 (Ruan et al. 2012). Both implantation serine proteinase ISP1 and 2 are serine proteinases essential for embryo hatching and implantation (Sharma et al. 2006). AEBSF, a general inhibitor of serine proteinases, can significantly inhibit embryo implantation in rats and attachment of mouse blastocysts on human epithelial cells (Jiang et al. 2011). Proprotein convertase 5/6 (PC6), a serine protease of the proprotein convertase (PC) family, is upregulated in the human endometrium specifically at the time of epithelial receptivity and stromal cell decidualization (Heng et al. 2011, Paule et al. 2015). High temperature requirement A4 (HTRA4) is a secreted serine protease highly expressed in the invasive extravillous trophoblasts that invade decidua. HtrA1 and HtrA3 interact with and degrade HtrA4 and thereby inhibit trophoblast-like JAR cell invasion (Chen et al. 2014). In our study, Prss56 is highly expressed in the primary decidual zone on day 5 of pregnancy, which is co-localized with COX-2 and mPGES-1, suggesting that Prss56 may regulate decidualization via stimulating COX-2 and mPGES-1 as trypsin does. Snail is also strongly expressed in the primary decidual zone (Ma et al. 2006), similar to Prss56 localization. We previously demonstrated that HB-EGF regulates snail expression through EGFR-ERK-Stat3 pathway (Jiang et al. 2013). However, the inhibitor of Stat3 has no effect on HB-EGF stimulation of Prss56 (data do not shown). At implantation site, Prss56 is co-localized with Egr1 (Liang et al. 2014). However, Prss56 expression is unaffected by Egr1 knockdown. Egr2 is another member of Egr family and highly expressed in primary decidual zone. Previous reports demonstrated that Egr2 knockout leads to a sharp decrease of Prss56 expression in boundary cap cells (Maro et al. 2004, Coulpier et al. 2009). Similarly, our results have shown that Egr2 knockdown downregulates Prss56 expression in mouse uterus. Based on our data, HB-EGF induction on Prss56 expression should play a role during mouse decidualization.

\section{Supplementary data}

This is linked to the online version of the paper at http://dx.doi.org/10.1530/ JOE-17-0636.

Declaration of interest

We declare that there is no conflict of interest that could be perceived as prejudicing the impartiality of the research reported.

\section{Funding}

This work was supported by National Basic Research Program of China (2013CB910803) and National Natural Science Foundation of China (31471397, 31272263 and 31671563).

\section{References}

Antalis TM, Bugge TH \& Wu Q 2011 Membrane-anchored serine proteases in health and disease. Progress in Molecular Biology and Translational Science 99 1-50. (doi:10.1016/b978-0-12-3855046.00001-4)

Chen YY, Chuang PY, Chen CP, Chiu YH, Lo HF, Cheong ML, Huang JY, Kuo PL \& Chen H 2014 Functional antagonism between high temperature requirement protein A (HtrA) family members regulates trophoblast invasion. Journal of Biological Chemistry 289 22958-22968. (doi:10.1074/jbc.M114.576744)

Coulpier F, Le Crom S, Maro GS, Manent J, Giovannini M, Maciorowski Z, Fischer A, Gessler M, Charnay P \& Topilko P 2009 Novel features of boundary cap cells revealed by the analysis of newly identified molecular markers. Glia 57 1450-1457. (doi:10.1002/glia.20862)

Das SK, Wang XN, Paria BC, Damm D, Abraham JA, Klagsbrun M, Andrews GK \& Dey SK 1994 Heparin-binding EGF-like growth factor gene is induced in the mouse uterus temporally by the blastocyst 
solely at the site of its apposition: a possible ligand for interaction with blastocyst EGF-receptor in implantation. Development 120 1071-1083.

Diao H, Xiao S, Li R, Zhao F \& Ye X 2013 Distinct spatiotemporal expression of serine proteases Prss 23 and Prss 35 in periimplantation mouse uterus and dispensable function of Prss35 in fertility. PLOS ONE 8 e56757. (doi:10.1371/journal.pone.0056757)

Evnin LB, Vasquez JR \& Craik CS 1990 Substrate specificity of trypsin investigated by using a genetic selection. PNAS $\mathbf{8 7}$ 6659-6663. (doi:10.1073/pnas.87.17.6659)

Gal A, Rau I, El Matri L, Kreienkamp HJ, Fehr S, Baklouti K, Chouchane I, Li Y, Rehbein M, Fuchs J, et al. 2011 Autosomal-recessive posterior microphthalmos is caused by mutations in PRSS56, a gene encoding a trypsin-like serine protease. American Journal of Human Genetics $\mathbf{8 8}$ 382-390. (doi:10.1016/j.ajhg.2011.02.006)

Hantak AM, Bagchi IC \& Bagchi MK 2014 Role of uterine stromalepithelial crosstalk in embryo implantation. International Journal of Developmental Biology 58 139-146. (doi:10.1387/ijdb.130348mb)

Heng S, Cervero A, Simon C, Stephens AN, Li Y, Zhang J, Paule S, Rainczuk A, Singh H, Quinonero A, et al. 2011 Proprotein convertase $5 / 6$ is critical for embryo implantation in women: regulating receptivity by cleaving EBP50, modulating ezrin binding, and membrane-cytoskeletal interactions. Endocrinology 152 5041-5052. (doi:10.1210/en.2011-1273)

Herington JL, Underwood T, McConaha M \& Bany BM 2009 Paracrine signals from the mouse conceptus are not required for the normal progression of decidualization. Endocrinology 150 4404-4413. (doi:10.1210/en.2009-0036)

Hollenberg MD, Mihara K, Polley D, Suen JY, Han A, Fairlie DP \& Ramachandran R 2014 Biased signalling and proteinase-activated receptors (PARs): targeting inflammatory disease. British Journal of Pharmacology 171 1180-1194.

Huang ZP, Yu H, Yang ZM, Shen WX, Wang J \& Shen QX 2004 Uterine expression of implantation serine proteinase 2 during the implantation period and in vivo inhibitory effect of its antibody on embryo implantation in mice. Reproduction, Fertility, and Development 16 379-384. (doi:10.1071/RD03102)

Jiang D, Yang Z, Li S, Xiao X, Jia X, Wang P, Guo X, Liu X \& Zhang Q 2013 Evaluation of PRSS56 in Chinese subjects with high hyperopia or primary angle-closure glaucoma. Molecular Vision 19 2217-2226.

Jiang YH, Shi Y, He YP, Du J, Li RS, Shi HJ, Sun ZG \& Wang J 2011 Serine protease inhibitor 4-(2-aminoethyl)benzenesulfonyl fluoride hydrochloride (AEBSF) inhibits the rat embryo implantation in vivo and interferes with cell adhesion in vitro. Contraception 84 642-648. (doi:10.1016/j.contraception.2011.03.017)

Lei W, Feng XH, Deng WB, Ni H, Zhang ZR, Jia B, Yang XL, Wang TS, Liu JL, Su RW, et al. 2012 Progesterone and DNA damage encourage uterine cell proliferation and decidualization through up-regulating ribonucleotide reductase 2 expression during early pregnancy in mice.
Journal of Biological Chemistry 287 15174-15192. (doi:10.1074/jbc. M111.308023)

Liang XH, Deng WB, Li M, Zhao ZA, Wang TS, Feng XH, Cao YJ, Duan EK \& Yang ZM 2014 Egr1 protein acts downstream of estrogen-leukemia inhibitory factor (LIF)-STAT3 pathway and plays a role during implantation through targeting Wnt4. Journal of Biological Chemistry 289 23534-23545. (doi:10.1074/jbc.M114.588897)

Liang XH, Zhao ZA, Deng WB, Tian Z, Lei W, Xu X, Zhang XH, Su RW \& Yang ZM 2010 Estrogen regulates amiloride-binding protein 1 through CCAAT/enhancer-binding protein-beta in mouse uterus during embryo implantation and decidualization. Endocrinology 151 5007-5016. (doi:10.1210/en.2010-0170)

Lim HJ \& Dey SK 2009 HB-EGF: a unique mediator of embryo-uterine interactions during implantation. Experimental Cell Research $\mathbf{3 1 5}$ 619-626. (doi:10.1016/j.yexcr.2008.07.025)

Ma XH, Hu SJ, Yu H, Xu LB \& Yang ZM 2006 Differential expression of transcriptional repressor snail gene at implantation site in mouse uterus. Molecular Reproduction and Development 73 133-141. (doi:10.1002/mrd.20429)

Maro GS, Vermeren M, Voiculescu O, Melton L, Cohen J, Charnay P \& Topilko P 2004 Neural crest boundary cap cells constitute a source of neuronal and glial cells of the PNS. Nature Neuroscience 7 930-938. (doi:10.1038/nn1299)

O'Sullivan CM, Ungarian JL, Singh K, Liu S, Hance J \& Rancourt DE 2004 Uterine secretion of ISP1 \& 2 tryptases is regulated by progesterone and estrogen during pregnancy and the endometrial cycle. Molecular Reproduction and Development 69 252-259. (doi:10.1002/mrd.20169)

Paria BC, Ma W, Tan J, Raja S, Das SK, Dey SK \& Hogan BL 2001 Cellular and molecular responses of the uterus to embryo implantation can be elicited by locally applied growth factors. PNAS 98 1047-1052. (doi:10.1073/pnas.98.3.1047)

Paule S, Nebl T, Webb AI, Vollenhoven B, Rombauts LJ \& Nie G 2015 Proprotein convertase $5 / 6$ cleaves platelet-derived growth factor A in the human endometrium in preparation for embryo implantation. Molecular Human Reproduction 21 262-270. (doi:10.1093/molehr/gau109)

Ruan YC, Guo JH, Liu X, Zhang R, Tsang LL, Dong JD, Chen H, Yu MK, Jiang X, Zhang XH, et al. 2012 Activation of the epithelial $\mathrm{Na}+$ channel triggers prostaglandin $\mathrm{E}(2)$ release and production required for embryo implantation. Nature Medicine 18 1112-1117. (doi:10.1038/nm.2771)

Salamonsen LA 1999 Role of proteases in implantation. Reviews of Reproduction 4 11-22. (doi:10.1530/ror.0.0040011)

Sharma N, Liu S, Tang L, Irwin J, Meng G \& Rancourt DE 2006 Implantation serine proteinases heterodimerize and are critical in hatching and implantation. BMC Developmental Biology 661 . (doi:10.1186/1471-213X-6-61)

Wang H \& Dey SK 2006 Roadmap to embryo implantation: clues from mouse models. Nature Reviews Genetics 7 185-199. (doi:10.1038/ $\operatorname{nrg} 1808)$

Received in final form 18 May 2017

Accepted 9 June 2017

Accepted preprint published online 12 June 2017 http://joe.endocrinology-journals.org

DOI: $10.1530 / J O E-16-0636$
๑) 2017 Society for Endocrinology Printed in Great Britain
Published by Bioscientifica Ltd. 